\title{
Science diplomacy as a foreign policy tool for Turkey and the ramifications of collaboration with the EU
}

\author{
Derya Buyuktanir Karacan (10) ${ }^{1 凶}$
}

As an emerging market economy and a candidate country for EU membership, Turkey has engaged in large-scale international science and research programs and organizations in Europe since the 1950s, and more intensely after its candidacy status commenced at the end of 1999. These engagements, which can be framed as Science Diplomacy (SD) efforts, were motivated by the Turkish government's perception that Turkey needs to become more integrated with the European countries, and must stay abreast of the science and technology developments or risk falling behind other EU candidate countries. The primary purpose of this paper is to explore how the emerging concept of SD helps explain transformations and changes in Turkish Science, Technology, and Innovation (STI) policies since 2000, with a special focus on engagements with the EU's science and research programs and European organizations, and subsequently filling a gap in related literature. Europeanization and qualitative content analysis are used as theoretical framework and methodology, respectively, to analyze these engagements. The key findings and conclusions point out that Turkey's efforts to harmonize its science and technology policies with the EU's has paved the way for new funding mechanisms and its participation in Horizon 2020 as an associated country. In addition, using Science and Technology (S\&T) cooperation as a soft power has strengthened the public diplomacy of Turkey with the European countries. As a result, increased involvement in STI partnerships with the European countries could help Turkey open new venues for developing its SD. However, despite the mutual economic and political benefit gained through scientific interactions, Turkey is still not using science as a diplomacy tool as effectively as it might to augment its foreign policy. It should be noted that research is one of the very few areas where the relations Turkey and the EU are still cooperating, regardless of growing tensions between the two parties. Thus, Framework Programs and other scientific projects that Turkey has participated in can provide founding experiences of Turkish SD with the EU, and may help Turkey open new venues for developing its SD. Nevertheless, a more resolute political will is needed.

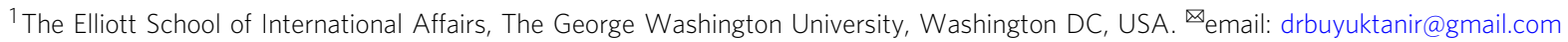




\section{Introduction}

urkey, the world's 19th largest economy (IMF, 2020), holds a unique position and importance within the context of the European Integration. It is the EU's 5th largest trading partner (European Commission, 2020a) with a growing economic market and dynamic business environment. Its geographically strategic position between the Mediterranean region and the Middle East, as well as its cultural ties with the rest of the Muslim world, singles out Turkey as a bridge between Europe and other countries. Moreover, Turkey's increasing importance as an energy transit route plays a vital role in European and global energy security (MFA, 2020a) and strengthens its position as a strategic partner for the EU (Agota and Tamas, 2017, p. 143). Recent international political crises, such as the Arab Spring and the current refugee flux towards Europe, have further increased Turkey's role and importance for the EU in a wider scope (Aydin Düzgit et al., 2013, p. 15).

EU-Turkey relations may be traced back to the beginning of the European Integration in the 1950s. Historically, political and cultural issues have caused complexity and uncertainty in the relationship between the two. Despite the dysfunction of the relationship in many areas, neither party has been willing to abandon it, as the mutual benefits gained from cooperating as partners is too valuable. To this end, Science and Technology (S\&T) has historically served as one of the more functional areas since, unlike many other areas, it is not usually shadowed by political disagreements. Engaging in S\&T cooperation can be one of the most effective means to address political challenges, or at least to maintain relations when there is an impasse, as it involves developing diplomatic solutions with the use of science as the common approach.

The concept of Science Diplomacy (SD) has entered into the EU's science, technology, and innovation (STI) policies as a strategic way of thinking about the role of science in foreign policy only in the last two decades. It is defined as an area of shared responsibility within the Union in order to increase collaboration on S\&T. As a corollary, SD has been also regarded as a novel way to emphasize the role of science and research programs in international relations and foreign policy in order to strengthen the relations with other countries, find solutions to global problems, and promote international development (Ruffini, 2017; Trobbiani and Hatenboer, 2018; Van Langenhove, 2016 , p. 21). Therefore, the EU has placed an increasing importance on S\&T program cooperation in order to advance its research and development (R\&D) capacity, to increase its influence as a global actor, and to strengthen its ties with other countries in the world. Among these countries, Turkey, as an EU candidate country, has become a partner by engaging in S\&T projects and research organizations that are fully or partially supported or coordinated by the EU or the European countries. Although the impacts for participating countries are not always equivalent, framework programs generally appear as an influential SD tool for connecting the national systems and research activities of member states and associated countries through funding mechanisms.

Despite the fact that SD has been embraced as a new tool for foreign policy mostly by developed countries, such as the US, Germany, Japan, the UK, and France, it is also becoming an emerging concept for developing countries. For Turkey, as an emerging market economy and a developing country, SD is also a very new concept. Although Turkey has engaged in different forms of scientific cooperation and activities, and has created diplomatic, cultural, and scientific relations with other countries, these efforts have not been conceptualized within the context of SD. For instance, bilateral and multilateral agreements, which aim mainly to cooperate in areas such as scientific research, technology, innovation, and development, can be considered building blocks of S\&T policies, and thus can be used to support SD (Dolan, 2012; Rüffin, 2017). ${ }^{1}$ As of April 2019, Turkey has 62 agreements with 50 countries and 318 ongoing cooperation research and innovation projects. Turkey has also participated in large-scale research programs, such as the European Organization for Nuclear Research (CERN) and European Space Agency (ESA), since the mid-1950s. It has also been involved in international scientific projects in Antarctica and as an observer in the SESAME project in the Middle East (Smith, 2012), and has participated in multi-stakeholder partnerships (Pearlman et al., 2016), all of which can be considered examples of Turkey's engagement in SD activities. In particular, S\&T cooperation through EU research and innovation framework programs can be considered one of the key tools of Turkey's SD in its attempt to maintain its relations with the EU. These interactions via framework programs have always been sustained at some level, although strained relations with many states have recently hampered stable scientific research planning (Flink, 2020, p. 262).

The primary purpose of this paper is to explore how the emerging concept of SD helps explain transformations and changes in Turkish STI policies since 2000, with a special focus on engagements with the EU's science and research programs and European organizations. The methodology employed in this paper is qualitative content analysis and Europeanization is used as the theoretical framework to analyze Turkey's engagement with the EU's S\&T and research programs, in particular during the early 2000s. Turkey's interaction with scientific networks and research communities in Europe has never been studied in international literature from the SD and foreign relations point of view. Therefore, this study fills a gap in the literature by offering analysis of Turkey's engagement in S\&T activities, particularly as they relate to the EU, and its need for SD as a new supporting mechanism for its foreign policy.

This paper develops in several sections. The section "Theoretical framework" provides brief background information about EU-Turkey relations and then defines Europeanization as a theoretical approach with its connection to SD, followed by an explanation of the methodology employed in the next section. In the section "The Science Diplomacy actors of Turkey and their current and potential roles", brief information about the main actors and their current and potential roles in Turkey's SD are presented. The next section covers examples of Turkey's engagement with the EU's SD through various programs and projects. In the penultimate section, the challenges and limitations that Turkey faces are discussed by revealing its recent $\mathrm{R} \& \mathrm{D}$ status and indicators. The final section summarizes the main findings and presents recommendations.

\section{Theoretical framework}

The literature on Europeanization has developed primarily in the context of the EU's enlargement (Schimmelfennig and Sedelmeier, 2015, 2007) and the impact of the EU on domestic politics and policies in member states and candidate countries (Cowles et al., 2001: Kaliber, 2013, p. 2). The beginning of the 2000s was especially critical for the EU, as the Union was experiencing its most significant enlargement. During this period, Europeanization literature included an analysis of the impact of the EU accession process on new members and candidate countries, including Turkey (Bölükbaşı et al., 2011, p. 78). After these years, a growing number of comparative analyses focused on the impact of the EU on member states' policies, politics, and institutions (Schimmelfennig et al., 2003). Although Europeanization is defined in various ways in international literature (Olsen, 2002), 
two of these definitions help us to analyze Turkey's cooperation with the EU in science and research and its efforts to harmonize its STI policies with the EU, in particular, during the early 2000s. These are the Börzel and Risse explanation of Europeanization as "a process of change at the domestic level in which the member states adapt their processes, policies, and institutions to new practices, norms, rules, and procedures that emanate from the emergence of a European system of governance" (Börzel and Risse, 2000), and Bulmer's description of the two dimensions of Europeanization as "the transfer from 'Europe' to other jurisdictions of policy, institutional arrangements, rules, beliefs, or norms, on one hand; and building European capacity, on the other hand" (Bulmer, 2007, p. 47). These definitions help to explicate how the EU strengthened the capacities for science and technology in member states and candidate states in a harmonized manner. Europeanization also helped to develop a more nuanced study of the various functions and roles of the EU for development of other countries' policy domains, and stimulated a discussion of the EU's actorness in international and global spheres (Schimmelfennig and Sedelmeier, 2015). International science cooperation and research programs can be regarded as tools to help the Union to achieve its goals not only to increase its competitiveness and foster its economic development, but to strengthen its relations with other countries as well. As a result, the image of the EU both as a norm power and market power has increased (De San Román and Schunz, 2018).

In order to gain a better understanding of Europeanization in Turkey, some brief information concerning EU-Turkey relations is necessary. Turkey's relationship with the EU, then the European Economic Community (EEC), was initiated formally by signing the 1963 Ankara Agreement, which was the association agreement with the Community, and was complemented eventually by an Additional Protocol signed in 1970. Once the EU and Turkey were linked by a Customs Union agreement (CU) in 1996, economic relations between the two began to develop at a faster pace. However, Turkey's quest towards EU membership took a major step when Turkey's candidacy status was recognized at the Helsinki Council in December, 1999 (Avcı and Çarkoğlu, 2011, p. 209; Akçay and Büyüktanır, 2013, pp. 2-12). Having been recognized as a candidate country for the EU, Turkey began negotiations towards membership in 2005. During that time, Chapter 25, "Science and Research," was the only chapter opened, and was then provisionally closed in June, 2006 (Directorate for EU Affairs, 2020a). A mere 5 years after completing the screening process in October 2006, relations between the two came to a halt. Reforms required by the EU for membership have, as of yet, not been completed, as the EU and Turkey still struggle with particular problems in some areas of reform and their implementation. Until now, only 16 of 35 policy chapters have been opened (Directorate for EU Affairs, 2020b), and most of the chapters are blocked by the EU Council and member states for political reasons. ${ }^{2}$ Recent circumstances, such as the Syrian refugee crisis (Büyüktanır Karacan, 2019, p. 144, 157), the military coup attempt in 2016, the opposition of some countries, such as France and Austria, to Turkey's membership, and the Eastern Mediterranean crises in 2020 have resulted in various negative effects on Turkey's relations with the EU, especially from the political perspective. Although alternative models to discuss Turkey's potential membership have been proposed (Müftüler-Baç, 2017), Turkey is moving away from its EU membership bid. Europeanization is not any more a motivation for Turkey, as it was in the early 2000s. Nevertheless, cooperation in science and research remains one of the very few areas where the relations are still maintained despite of political tensions between Turkey and the EU.

Before the 1999 Helsinki Summit, when Turkey's candidacy was yet to be considered, the literature related to the EU in
Turkey was profoundly focused on the European integration theories and EU-Turkey relations (Bölükbaşı et al., 2011, p. 91). Conceptual, theoretical, and methodological studies of the Europeanization of Turkey commenced at the beginning of 2000, and, as Kalibar states, "Europeanization as a wider socio-political context began to penetrate into Turkish politics and society more deeply than ever before" (Kalibar, 2013, p. 12). In Turkey Europeanization was employed as a theoretical concept to study the impact of the EU on Turkey's national policies and programs mainly after its candidacy was recognized in 1999 at the Helsinki Summit and the EU's international actorness and transformative role began to be analyzed along with the European Integration theories (Avc1 and Çarkoğlu, 2011; Müftüler-Baç, 2005). The studies conducted in Turkey from the Europeanization perspective have been concentrated mostly on areas such as foreign policy (Oğuzlu, 2008; Öniş and Yılmaz, 2009), conditionality (Aydın and Açıkmeşe, 2009), and human rights (Samur, 2009; Grigoriadis, 2008; Tocci, 2006). There are some areas, such as environment, agriculture, public health, and culture, which are analyzed as well, but less often (Bölükbaşı et al., 2011, p. 82, 83), including S\&T, where there are a limited number of studies conducted from the Europeanization perspective. Ulutaş-Aydogan's study focusing on the Europeanization of the Turkish Research Area (TRA) and Turkish STI policies from an economic development perspective (Ulutaş-Aydoğan, 2015) is one of those few.

The key points for understanding Europeanization and how it relates to the STI-based development goals of Turkey and membership to the EU can be observed in Turkey's policy documents issued mainly during the early 2000s. All of these policy transformations have designated scientific interaction as a new tool to align Turkey's national goals with those of the EU's. The policy documents referenced below indicate close correlations between the goals of Turkey and the EU towards increasing competitiveness and achieving social and economic development, as well as for achieving better integration.

The decisions that led to the evolution of Turkey's STI policies and its efforts to integrate with the EU can be observed mainly in the Science, Technology and Innovation Policies Council (STIPC) meeting decisions. ${ }^{3}$ As the highest-ranking advisory body to Turkish Government, STIPC plays an important role in decision making on national STI policies. The meetings held after 2000 explicitly included topics regarding integration with EU policies and engaging in the EU's framework programs. For instance, the STIPC meeting that coincided with the initiation of Turkey's full candidacy to the EU in 1999 was held in 2000, and focused on developing a national STI policy to be integrated with the EU's. The decisions reached at this meeting included the adaptation of "Turkish Science and Technology Policies Strategy 2003-2023," which was used as an outline for the first Turkish S\&T foresight study, "Vision 2023: Science and Technology Strategies" in 2001. Vision 2023 aimed at steering Turkey towards becoming one of the 10 largest economies in the world, reaching a goal of investing 3\% of its Gross Domestic Expenditure in R\&D (GERD) by 2023. To this end, the EU was highlighted as a major reference point in the economic development of Turkey (TUBITAK, 2004). The overlap between the European and Turkish grand objectives to achieve a knowledge-based economy was also emphasized (Apaydın, 2015; Ulutaş-Aydoğan, 2015, p. 269).

The Turkish Research Area (TRA) ${ }^{5}$ concept, aligned with the European Research Area (ERA), was referenced in Vision 2023, as well as in the STIPC meeting in 2003, to the result of the EU and Turkey sharing common STI-based development goals. The TRA was drafted to be consistent with EU policies and the ERA that links the EU and national research and innovation systems via ERA-NETs and Joint Programing Initiatives (JPIs) to improve 
their performance (Ulutaş-Aydoğan, 2015, p. 269, 304). Moreover, in STIPC meetings held in 2005 and 2006, participation in Framework Programs was discussed as it related to benefitting Turkey's social and economic development. The Framework Programs were argued as invaluable for Turkey to integrate with the ERA in order to be competitive so that the gap between Turkey and the EU and other candidate countries would not widen. Additionally, the 2005, 2006 and 2007 meetings recognized the use of STI in international relations (Ulutaş-Aydoğan, 2015, p. 269, pp. 303-304). This recognition was also aligned with the EU's aim to support its foreign policies and to strengthen its research excellence and international cooperation through Horizon 2020 (European Parliament, 2015).

As briefly explored above, Turkey undertook changes to its own national policies and programs in the attempt to harmonize them with the EU and to fulfill the conditions necessary to participate in European Community programs (Erdil and Gossart 2009, pp. 6-7). All of these efforts opened new funding mechanisms under the Pre-Accession Instruments (IPA) (European Commission, 2016, p. 3), and later led to Turkey's participation in Horizon 2020 as an associated country. During the analytical examination of the acquis (screening) process, Turkey ensured the implementing necessary capacities to pursue Community objectives and activities in the field of research and technological development, including adequate staffing for "designing and applying an integrated research strategy" (European Commission, 2006). During its accession period, Turkey has restructured its policies and institutions to engage in programs on S\&T in line with the EU guidelines and norms. The perception that Turkey needs to become more integrated with the other European countries, and should not fall behind other candidate countries by staying abreast of the S\&T developments in the EU, led to transformations and changes in Turkish STI policies. ${ }^{6}$ Turkey has been an associated county of the EU's Framework Programs since 2002, participating in various research cooperation activities and scientific programs, and encouraging the mobility of youth and researchers to European countries (Agota and Tamas, 2017). Additionally, in order to integrate with the European Research Area (ERA), Turkey has utilized instruments such as the Joint Programming Initiatives (JPI) and the ERA-NET scheme with the aim of benefiting from the EU S\&T programs to strengthen its economic growth, development, and competitiveness and to reach its aim of being one of the most dynamic and competitive knowledge economies in the world.

Europeanization, mainly as a policy adaptation process, was a driving force for Turkey to develop more harmonized S\&T partnerships with the EU for the first 10 years of the 2000s. Although STI-related interactions do not directly impact political relations between Turkey and the European member countries, they help relations function at some level and help Turkey remain part of the European integration. Cooperation regarding research and collaboration on S\&T between Turkey and the EU is one the very few areas the relations have been maintained regardless of growing tensions between two parties. In that respect, Framework Programs and other scientific projects that Turkey has participated in can provide noble examples for Turkish SD, even in periods of diplomatic tension. Furthermore, the willingness of STI actors to increase the collaboration with European universities and research organizations has helped Turkey strengthen its S\&T capacity and research agenda. The EU influence in STI-related areas might be the case for not only Turkey's adaptation of policies in line with the EU, but, at the same time, participating in more STI partnerships and engaging in different joint partnerships with the European countries may help Turkey open new venues for developing its SD. From this perspective, Turkey's SD in cooperation with the EU and the European countries may prove a catalyst in promoting Turkey's efforts to realize SD activities with other countries.

\section{Methodology}

In this study, the qualitative content analysis method was employed. Qualitative content analysis is defined by Holsti (1968, p. 608) as "Any technique for making inferences by systematically and objectively identifying special characteristics of messages." It is used to process the information for interpretation and in-debt analysis for making conclusions and inferences about the research question. In this work, the method was applied in two phases, as explained in the following paragraphs.

In the first phase, relevant information available as electronic and printed materials in primary and secondary sources were compiled and aggregated. In this phase, reports, policy papers, EU official communications, directives, press releases, and speeches released and produced by the respective organizations of Turkey and the EU were used as primary sources to gather information. Reports published by intergovernmental organizations, such as the World Bank (WB) or Organization for Economic Cooperation and Development (OECD), were also reviewed in order to include the latest statistics on Turkey's R\&D indicators to compare with the EU's, and, subsequently, to interpret Turkey's performance. To complement the primary sources, books, journal articles, and digital and printed documents were used as secondary sources. The information from these sources was gathered according to the pre-identified topics of importance to the research objectives. Since there was an excessive number of texts/ documents, findings were narrowed by selecting the most recent and relevant documents addressing the study's research question. In the second phase, the information was analyzed systematically by categorizing it into two groups: actors, policies, and institutions as the first group, and EU-Turkey relations, Europeanization, and $\mathrm{SD}$ as the second one. From the second group, EU-Turkey relations were employed as background for the theoretical framework. Turkey's initiatives for harmonizing its policies with the EU and the benefits of engagement afforded by science and research partnerships with the EU were analyzed through Europeanization.

The results of the content analysis of Turkey's SD were interpreted with respect to three dimensions of SD (Royal Society, 2010), which are briefly explained below.

1. Science in Diplomacy (SinD) is about "building capacity to give and receive scientific advice in the foreign policy community." It helps to answer questions such as, "How does Turkey use scientific advice in fulfilling its foreign policy objectives? And what are the opportunities for researchers who engage in EU research programs and collaborate with other researchers from various countries to play a role in the Turkish government's advice mechanisms?"

2. Diplomacy for Science (D4S) can be briefly summarized as "facilitating international science cooperation," and attempts to answer questions such as, "How does Turkey's engagement in the EU's S\&T programs and funding opportunities strengthen its national R\&D capacity?"

3. Science for Diplomacy (S4D) is about "using science cooperation to improve international relations between countries." Under the scope of this dimension, the question, "how does Turkey benefit from science cooperation (bilateral, multilateral, and regional levels) to improve its international relations where conventional diplomacy actors and tools have not been successful or sufficient?" can be addressed. 
In this study, as will be discussed in the next sections, two of these dimensions, namely D4S and S4D are the main dimensions for Turkey, as SinD has not yet developed fully.

Furthermore, in order to make the analysis of Turkey's SD efforts with the EU more systematic and categorized, we utilized three classifying tools (Van Langenhove, 2017, pp. 12-17): strategic, operational, and support. These include the following:

1. Strategic tools: Policy documents that provide directions for actors to achieve their policy goals.

2. Operational tools: Policy instruments for putting SD into practice and allocating specific resources, as well as the mechanisms identifying how to use them.

3. Support tools: Informational events and training involving activities that aim to promote or facilitate SD.

The highlights of Turkey's engagement with each of these are summarized in detail under two different sections. The strategic tools are scrutinized under the "Theoretical framework" section, which analyzed the STI policy documents related to Turkey's efforts to integrate with the EU, and the operational and support tools are analyzed in detail under "Turkey's engagement with the EU's science diplomacy” section.

\section{The SD actors of Turkey and their current and potential roles} SD is a new concept to Turkey. Therefore, there are only few actors with clearly defined roles related it. Most of the roles and activities considered part of SD are distributed and performed by existing key actors/stakeholders in the Turkish STI ecosystem and its policy making. Therefore, it is necessary to discuss these actors and their roles in order to be able to analyze Turkish SD. Besides the Turkish Ministry of Foreign Affairs, other ministries, governmental bodies, actors/stakeholders from the private sector, industry, research and academic sector and civil society play actual or potential roles in integrating and creating relations with stakeholders in other countries as part of scientific partnerships to find solutions for global problems. These actors sign agreements, join multinational research and education programs and initiatives, and establish relations with their counterparts in other countries. ${ }^{7}$ In this study, only the main actors with actual and potential roles are analyzed.

Two ministries primarily play fundamental roles in the STI policies of Turkey. ${ }^{8}$ These are the Ministry of Industry and Technology (MoIT) and the Ministry of Foreign Affairs (MFA). $\mathrm{MoIT}^{9}$ signs multi and bilateral agreements with other countries and organizes state-level meetings on STI-related topics, including trade, industry, economy, science, and technology. This ministry places a special emphasis on relations with the EU by signing international agreements with its member states (MoIT, 2019a, 2019b). The Turkish Ministry of Foreign Affairs (MFA), with its diplomatic and consular missions in other countries and diplomatic representations in international organizations (MFA, 2020b), plays a critical role in formulating Turkey's foreign policy and realizing diplomatic activities. However, it has still not fully engaged in SD. For instance, even though it has signed a protocol with the MoIT in 2013 promising to appoint science attachés in selected Turkish Embassies in different countries, these science attachés have still not been appointed.

In addition to MoIT and MFA, the Science, Technology and Innovation Policies Council (STIPC), ${ }^{10}$ as the highest-ranking advisory body to the Turkish Government, performs a special role for decision-making on national STI policies, and leads the strategy and advancement of STI activities and collaborations in Turkey (Apaydın, 2015). STIPC maintains the role of identifying, monitoring, and coordinating policies in accordance with national goals and interests for economic and social development
(Özkaraöz Doğan, 2015, p. 168; Ozer-Imer and Imer, 2020, p. 5). It includes representatives from governmental and nongovernmental actors in Turkey to define priority areas, and serves as a systematic and unified decision mechanism in policy making. As explained in the "Theoretical framework" section, the STIPC meetings and reports are the main policy venues where Turkey's STI roadmap is discussed and determined in the context of social and economic development and harmonization efforts in line with EU policies. STIPC has not a direct role in practicing/ implementation SD, but rather plays a leading role in defining Turkey's STI priorities and identifying the policies. Therefore, its policy-making role implicitly strengthens the Turkey's SD by playing a pivotal role in defining state interests.

The Scientific and Technological Research Council of Turkey (TÜBİTAK), established in 1963, acts as an advisory agency to the Turkish Government concerning science and research issues (TÜBİTAK, 2019). It also acts as secretariat for the STIPC. TÜBİTAK has played a crucial role in Turkey's engagement with the EU programs by assuming the contact role for the EU Framework Programs since 2002 (TÜBİTAK, 2003). TÜBİTAK EU Framework Programs National Coordination Office (NCO) coordinates the EU Framework Programs, currently the $8^{\text {th }}$ Framework Program (Horizon, 2020), and will probably organize the upcoming one - Horizon Europe. In addition to these activities, TÜBİTAK supports Turkey's SD, especially the D4S dimension, by creating bilateral cooperation at inter-governmental or interinstitutional levels, and by cooperating with international and regional organizations and research projects, such as COST (European Cooperation in the field of Scientific and Technical Research), ESA (European Space Agency), ESF (European Science Foundation), EMBC (European Molecular Biology Conference), the Black Sea Economic Cooperation, NATO, OECD, and UNESCO (Geothermica, 2020). In addition, it conducts in-house research in strategic areas in its research centers, and develops support programs for public and private sectors (TÜBİTAK, 2019).

The Turkish Academy of Sciences (TÜBA) is another organization that maintains contacts with more than 50 academies from over 40 countries in the Council of Europe region, including almost all EU Member States (TÜBA, 2020b). TÜBA plays a potential role in extending Turkey's SD by strengthening relations with other countries and organizations through maintaining bilateral relations with foreign academies and multilateral relations with international organizations (TÜBA, 2020a), and also by organizing bilateral exchange programs to foster mutual exchange of scientific knowledge and experiences among scientists. ${ }^{11}$ Further, it can function as an independent body to provide scientific advice to policy makers in Turkey for more effective implementation of SD.

The Yunus Emre Institute (YEI), is a relatively new actor in Turkey's SD. Although it promotes mainly the public and cultural diplomacy of Turkey (Ekşi, 2016, p. 27-33; Kaya and Tecmen, 2011), it has recently engaged in Turkey's SD by promoting Turkey's academic, scientific, and technological capacity abroad and by creating scientific and academic interaction. A project in collaboration with TÜBİTAK, called the Turkish Academic and Scientific Cooperation Project (TABIP), was started to promote SD activities in Turkey and to improve Turkey's recognition in the academic fields by fostering scientific collaboration (YEI, 2019a). In addition to YEI's more than 58 cultural centers abroad (YEI, 2019b), it is currently collaborating with 80 universities in 60 countries. Furthermore, YEI provides increased importance to relations with the EU. Brussels one of its first locations, has assigned science advisors since 2018 (YEI, 2019c). YEI fulfills a particular role in S4D aimed at supporting the public diplomacy of Turkey through science as soft power. 


\section{Table 1 The actors of SD in Turkey.}

\begin{tabular}{|c|c|c|}
\hline Organization & Mission and objectives & STI and SD tools and activities \\
\hline $\begin{array}{l}\text { Ministry of Industry and } \\
\text { Technology (MolT) }\end{array}$ & $\begin{array}{l}\text { - Design, determine, and implement STI policies and } \\
\text { strategies of Turkey } \\
\text { - Promote and encourage R\&D and innovative programs and } \\
\text { projects } \\
\text { - Lead other governmental bodies }\end{array}$ & $\begin{array}{l}\text { - Multi and bilateral agreements with other } \\
\text { countries }\end{array}$ \\
\hline $\begin{array}{l}\text { Turkish Ministry of Foreign } \\
\text { Affairs (MFA) }\end{array}$ & $\begin{array}{l}\text { - Conduct foreign relations of Turkey } \\
\text { - Formulate Turkey's foreign policy and realize diplomatic } \\
\text { activities } \\
\text { - Strengthen Turkey's existing strategic relationships and } \\
\text { establish new ones }\end{array}$ & $\begin{array}{l}\text { - } 246 \text { diplomatic and consular missions in } \\
\text { other countries, but still no appointed } \\
\text { science diplomats or attachés } \\
\text { - Diplomatic representations in international } \\
\text { organizations } \\
\text { - Public diplomacy activities }\end{array}$ \\
\hline $\begin{array}{l}\text { Science, Technology and Innovation } \\
\text { Policies Council (STIPC) }\end{array}$ & $\begin{array}{l}\text { - Determine STI policies } \\
\text { - Identify, monitor, and coordinate STI policies in accordance } \\
\text { with national goals and interests } \\
\text { - Lead the strategy and advancement of STI activities and } \\
\text { collaborations }\end{array}$ & $\begin{array}{l}\text { - Policy documents (STIPC Meeting Reports), } \\
\text { and reports on the vision, priorities, and } \\
\text { main targets of STI. }\end{array}$ \\
\hline $\begin{array}{l}\text { The Scientific and Technological } \\
\text { Research Council of Turkey (TÜBiTAK) }\end{array}$ & $\begin{array}{l}\text { - Support the government in preparation and implementation } \\
\text { of the STI policies and carry out secretariat activities } \\
\text { of STIPC } \\
\text { - Play a role in Turkey's engagement with the EU programs } \\
\text { and in coordinating EU projects and programs in Turkey } \\
\text { - Cooperate with international and regional organizations }\end{array}$ & $\begin{array}{l}\text { - Bilateral and multilateral cooperation with } \\
\text { regional and international scientific and } \\
\text { research organizations } \\
\text { - National and international support programs } \\
\text { for public and private sectors }\end{array}$ \\
\hline $\begin{array}{l}\text { The Turkish Academy of Sciences } \\
\text { (TÜBA) }\end{array}$ & $\begin{array}{l}\text { - Encourage research, honor researchers, direct youth } \\
\text { towards science and research } \\
\text { - Raise and protect the societal status of scientists and } \\
\text { researchers } \\
\text { - Provide consultancy in scientific issues and determine } \\
\text { scientific priorities }\end{array}$ & $\begin{array}{l}\text { - Bilateral and multilateral relations with } \\
\text { foreign academies and international } \\
\text { organizations. } \\
\text { - Bilateral Exchange Programs } \\
\text { - Agreements with research organizations }\end{array}$ \\
\hline The Yunus Emre Institute (YEI) & $\begin{array}{l}\text { - Promote public and cultural diplomacy of Turkey } \\
\text { - Engage in Turkey's SD by promoting Turkey's academic, } \\
\text { scientific, and technological capacity abroad and by creating } \\
\text { scientific and academic interaction }\end{array}$ & $\begin{array}{l}\text { - Collaborations with } 80 \text { universities in } 60 \\
\text { countries with its } 58 \text { cultural centers abroad }\end{array}$ \\
\hline
\end{tabular}

Table 1 summarizes institutions and organizations related to STI polices and SD in Turkey.

\section{Turkey's STI policy documents related to its efforts to integrate with the EU}

Turkey's STI policies on collaborating with other countries and establishing cooperation mechanisms are highlighted in various policy documents. STIPC meeting decisions/reports, the Vision 2023 Strategy Paper, the Science Technology and Innovation National Strategy (2011-2016) document, and National Development Plans are the major policy and SD references regarding Turkey's efforts to align its national strategies with EU activities and polices.

As the highest-ranking advisory body to Turkish Government, STIPC plays an important role in decision making on national STI policies. As such, the decisions that led to the evolution of Turkey's STI policies and its efforts to integrate with the EU can be observed in these meetings. The first meeting of STIPC in 1989 was important because it defined the current state of Turkey's STI policy, and the first proposals for strengthening Turkey's R\&D capacities were presented. At the 1997, 1998, and 1999 meetings, decisions regarding new tools and steps were taken that would enable structuring a national innovation system for these objectives (TÜBİTAK, 2019). However, the meetings held after 2000 explicitly included topics regarding integration with the EU policies and engaging in the EU's framework programs. Therefore, it is necessary to discuss briefly the important points declared in these meetings.

The sixth meeting, which coincided with the initiation of Turkey's full candidacy to the EU in 1999, was held in 2000, and focused on developing a national STI policy to be integrated with the EU's. The decisions reached at this meeting included the adaptation of "Turkish Science and Technology Policies Strategy 2003-2023," which was used as an outline for the first Turkish S\&T foresight study, "Vision 2023: Science and Technology Strategies" in 2001. ${ }^{12}$ Vision 2023 aimed at steering Turkey to become one of the largest 10 economies in the world, reaching a goal of investing 3\% of its Gross Domestic Expenditure in R\&D (GERD) by 2023, and the EU was highlighted as a major reference point in economic development of Turkey (TUBITAK, 2004). The overlap between the European and Turkish grand objectives to achieve a knowledge-based economy was also emphasized (Apaydın, 2015; Ulutaş-Aydoğan, 2015, p. 269). After mentioning the common STI-based development goals of the EU and Turkey, the Turkish Research Area (TRA) ${ }^{13}$ concept, aligned with the European Research Area (ERA), was given reference in Vision 2023, as well as in the 9th meeting in 2003. The TRA was drafted to be consistent with EU policies and the ERA that links the EU and national research and innovation systems via ERANETs and Joint Programing Initiatives (JPIs) to improve their performance (Ulutaş-Aydoğan, 2015, p. 269, 304). As a consequence, in the 11th (2005) and 14th (2006) STIPC meetings, participation in Framework Programs was discussed as it related to benefitting Turkey's social and economic development. The Framework Programs were argued as invaluable for Turkey to integrate with the ERA in order to be competitive so that the gap between Turkey and the EU and other candidate countries would not widen. The key priority areas in STI were approved at the 22nd meeting of the National Science, Technology and Innovation Strategy (2011-2016). Moreover, the 11th (2005), 14th 
Table 2 Turkey's engagement in major European organizations and programs on STI and research.

\begin{tabular}{|c|c|c|c|}
\hline & Organization/Program & $\begin{array}{l}\text { Year of } \\
\text { establishment }\end{array}$ & Turkey's status-explanation \\
\hline CERN & European Organization for Nuclear Research & 1953 & $\begin{array}{l}\text { Granted observer status at CERN in } 1961 \text { and became an } \\
\text { associate member of CERN in } 2015\end{array}$ \\
\hline EMBC & European Molecular Biology Conference & 1969 & Member country \\
\hline COST & European Cooperation in S\&T & 1971 & $\begin{array}{l}\text { Member country-Turkish Researchers very active in COST } \\
\text { actions } \\
259 \text { COST actions as of } 2019 \text { (COST, 2019). }\end{array}$ \\
\hline ESF & European Science Foundation & 1974 & TÜBITAK an associate member of ESF \\
\hline ESA & European Space Agency & 1975 & Signed cooperation agreement in 2004 \\
\hline FPs & Framework Programs & 1984 & $\begin{array}{l}\text { Participated to the FP6 (2002-2006), FP7 (2007-2013) } \\
\text { and to Horizon } 2020 \text { (2014-2020). Realized project- } \\
\text { based participation to FP4 and FP5 as well. }\end{array}$ \\
\hline EUREKA & $\begin{array}{l}\text { Intergovernmental network for international R\&D\&l } \\
\text { cooperation }\end{array}$ & 1985 & $\begin{array}{l}\text { Members } 1985 \text { Chairmanship: 1998-1999 and 2012-2013 } \\
36 \text { Projects as of } 2018 \text { (EUREKA, 2018) }\end{array}$ \\
\hline Erasmus + & EU Program for education, training, youth, and sport & 2014 & $\begin{array}{l}\text { Actively participate in Erasmus }+ \text { as a Non-EU Program } \\
\text { Country }\end{array}$ \\
\hline
\end{tabular}

(2006), 15th (2007) and 25th (2013) meetings recognized the use of STI in international relations as well (Ulutaş-Aydoğan, 2015, p. 269, pp. 303-304). This recognition was also aligned with the EU's aim to support its foreign policies and to strengthen its research excellence and international cooperation through Horizon 2020 (European Parliament, 2015).

National Development Plans (DP) also covered the Turkish government's intentions to integrate with the EU in STI. The EU is emphasized in most of these plans, and is highlighted as one of the most important partners to Turkey for developing its essential skills in R\&D. Starting from the 5th DP, and covering the period 1985-1989, the EU membership process was presented as an opportunity for utilizing the advantages of globalization, while other DPs covered Customs Union, increasing R\&D investments, and increasing the number of researchers (Ulutaş Aydoğan, 2015, pp. 250-253). ${ }^{14}$

All these policy documents designed a roadmap for economic development and created a national research and innovation system to align national goals with those of the EU's. The key points for understanding Europeanization and how it relates to the STI-based development goals of Turkey and full membership can be observed in Turkey's policy documents. These policy references also indicate close correlations between the goals of Turkey and the EU towards increasing competitiveness and achieving social and economic development, as well as for achieving better integration.

\section{Turkey's engagement with the EU's SD}

$\mathrm{SD}$ has been recognized by the EU as an increasingly important tool for improving cooperation with countries throughout the world (European Parliament, 2015). The policies and tools designed for broader STI cooperation have paved the way for the EU to enhance its attractiveness and competitiveness and to strengthen its external relations. The external dimension of SD is stated clearly in the Lisbon Treaty (TFEU) in Article 180(b) by indicating that the EU will "promote S\&T with third countries while complementing that of the Member States" (EUR-lex, 2012). Turkey, as a candidate country, was listed in the category of "EU enlargement countries" (European Commission, 2016) and became an associated country for the Horizon 2020 program with the opportunity to access the same research and innovation privileges granted Member States (European Commission, 2020b). ${ }^{15}$

Turkey's involvement in European science and technology organizations and programs has a longer history than the early 2000s. Previous to the Framework programs, Turkey engaged in various organizations and programs initiated or supported by the EU and European countries beginning in the mid-1950s. However, although these S\&T involvements can still be framed with SD, they did not occur as a result of a policy adaptation process, unlike those after 2000 that were initiated as part of the harmonization efforts with the EU.

As explained in the methodology section, to make the analysis more systematic and categorized, three classifying tools-strategic, operational, and support-identified by Van Langenhove (2017, pp. 12-17) were utilized. Turkey's engagement with each of these tools is explained, as follows:

1. Strategic tools: Turkey's STI policy documents presented in previous sections can be considered strategic tools. Although Turkey's national interests are the main priority in all these STI documents, the preparers were, at the same time, taking into consideration the EU's norms or directions in order to strengthen relations with the EU and to better integrate into the Union's STI-related programs and organizations.

2. Operational tools: The EU has initiated inclusive, comprehensive, and high-budgeted international S\&T programs and tools for cooperation over the past decades. These initiatives, as part of their operational tools targeting the associated and third countries for the aim of opening its research area to the world, paved the way for Turkey to benefit from programs such as ERA-NETS, EUREKA, COST, and framework programs. Examples of these programs and organizations that Turkey engaged in were presented briefly in Table 2 .

Framework programs can be considered one of the most influential tools for connecting national systems, funding mechanisms, and research activities of the member states and the associated countries. Additionally, these programs are still the most critical international policy cooperation instruments for policy makers (Ulustaş-Aydoğan, 2015, 
pp. 264-265, p. 272). As Turkey's membership process is considered, the policy aspect of framework programs is seen as an important tool for S4D and D4S aspects. Horizon 2020, the most significant EU Research and Innovation program, with nearly $€ 80$ billions of funding, is one of the most influential operational tools of SD. Horizon 2020 was planned for seven years (2014-2020), and encompassed programs such as the European Research Council (ERC) and the Marie Skłodowska-Curie Actions (MCSA), Euratom, programs on "Science with and for Society," as well as "Societal Challenges," and "Industrial Leadership" (European Commission, 2019a). For instance, MCSA individual fellowships, a prestigious fellowship program, contributed funds for successful Turkish researchers to conduct part of their research in another European country and to initiate collaborations with other researchers. Between 2014 and 2019, 456 researchers were funded by MSCA, and the EU contributed $€ 22.75$ million to Turkish organizations (European Commission, 2019b). Another example is the ERC's open competition for funding, which has resulted in becoming a primary source for researchers in Turkey (Ufuk $2020,2019)$, as with researchers in any other EU country, to apply for funding through proposal submission. ${ }^{16}$

Besides the Framework programs, Turkey's engagements with European level initiatives (extensive research organizations) on S\&T also help it to cooperate with other countries and create international links related to global issues. As a result, Turkey has assumed roles in large-scale research institutions that have been funded or coordinated by European countries. For instance, it was granted observer status at the European Organization for Nuclear Research (CERN) in 1961, and became an associate member of this organization in 2015. Moreover, Turkey participated in organizations and programs such as COST (European Cooperation in the field of Scientific and Technical Research), European Space Agency (ESA), European Science Foundation (ESF), the Intergovernmental Network for International R\&D\&I Cooperation (EUREKA), and the European Molecular Biology Conference (EMBC).

Various actors in Turkey signed agreements with their counterparts in other countries in order to better engage the operational aspect of the EU's SD. In addition to agreements signed by TÜBA with other European countries, TÜBİTAK has also coordinated various small and large-scale research projects. It has also organized bilateral cooperation with different countries at the inter-governmental or interinstitutional levels to support and monitor common research by providing financial support for scientific meetings and exchange of scientists, and to support research projects. Additionally, Turkey participated in EU programs such as Erasmus+ and Erasmus Mundus, supporting the mobility of students, staff, and researchers. These programs present various levels of participation by university staff or researchers, and are open to students, staff in primary or secondary schools, and other participants representing the private sector and NGOs.

Table 2 provides examples of Turkey's engagement in major research organizations and international/multinational programs in Europe.

3. Support tools: In order to support, promote, or facilitate SD in Turkey, an increased number of awareness activities have been realized since the beginning of 2010. Workshops, training, dialog, and consultation activities have been organized by institutions, such as TÜBİTAK and the Yunus Emre Institute. The EU also has been supporting a project called "Turkey in Horizon 2020", ${ }^{17}$ which was started in
2015 to organize training and networking activities and to provide consultancy for small and medium size enterprises (SMEs). Additionally, EURAXESS Turkey helps to inform Turkish scientists and researchers about the EU's funding and job opportunities, promotes their participation in various EU programs, projects, and research positions in European countries, and supports their career development in Turkey through various support services.

The benefits and rationale of Turkey's engagement in these programs and European S\&T research structures can be summarized from the perspectives of Flink and Schreiterer (2010, pp. 669-670). Turkey has accessed to researchers, research findings, facilities, and research infrastructures through S\&T engagements, and it has undertaken involvement in large-scale science projects which it cannot afford to run alone. All these engagements have supported its innovation capacity and laid grounds for sustainable international partnerships with the EU, its member states, and other countries. At the same time, Turkey has also internationalized its higher education. Furthermore, Turkey, as an associated country for Horizon 2020, has seized international funding opportunities for its researchers and accessed European research infrastructures, which has led to promoting its achievements in R\&D and attracting students, researchers, and S\&T companies to Turkey. As a result, benefiting from EU programs has helped Turkey to reach its aim of becoming one of the most dynamic and competitive knowledge economies in the world, as envisioned in its Vision 2023 Strategy.

\section{Challenges and limitations of Turkey's engagement in the EU's science and research programs}

The implementation of SD may be different in each country as a result of the intrinsic economic and political structures of each one, and is affected by the bilateral interactions and long-standing issues between states. In Turkey, SD has not been traditionally perceived as part of its foreign relations, being employed mainly as a tool for enhancing its R\&D capacity and economic development. Although Turkey has potential capacity and resources to practice SD more inclusively in all aspects with the EU and the European countries, it faces some challenges in the effort to mobilize these resources. Barriers and limitations regarding full implementation of SD can be analyzed from different perspectives. The most important barrier to applying SD to foreign relations and including a science advice mechanism to policymaking appears to be the lack of political will. On the other hand, the complex structure of the EU programs and funding mechanisms, as well as Turkey's R\&D capacity and research ecosystem, can also be considered challenges for facilitating international science cooperation.

Turkey's engagement with EU-supported or initiated research projects and S\&T programs has been continuing with the EU even during politically tense times. In fact, since science is (or should be) generally isolated from the political landscape, purely scientific activities can continue to sustain relations at other levels too. By the same token, the positive contributions of engaging in S\&T to overcome political challenges and to improve relations could be better taken advantage of if Turkey had appointed science attachés or diplomats at Turkish Embassies and Consulates in the European countries. Although the first attempts for appointing science attachés were initiated by the Ministry of Industry and Technology in $2013,{ }^{18}$ it has still not yet been completed since then largely because it is no longer considered a priority by policy-makers. In reality, as in many other countries, such as Germany, the UK, and France, prominent Turkish scientists and researchers can be employed as science advisors to the Ministry of Foreign Affairs or as science attachés at an embassy 
with a more resolute political will. Furthermore, science diplomats who potentially create more diplomatic channels and connect with different research and technology communities may help Turkey to develop its relations with other countries (Büyüktanir, 2018, p. 76; Olcay, 2011, pp. 136-137), especially as it affects its membership bid by increasing its strategic approach in foreign relations with a wider and updated perspective during its accession process. Absence of science diplomats/advisors/ attaches to guide the government in its international relations can be regarded as a significant barrier for implementation of the S4D dimension of SD in Turkey.

Another barrier is Turkey's rapidly changing domestic and international political agenda, in lieu of a consistent and longterm outlook for development, which always dominates other policy areas that are not as visible. As a result of national security concerns, R\&D investment focuses on specific priority areas, such as military and defence, which are usually confidential and not accessible for international collaboration, as opposed to ICT, basic sciences, and environmental initiatives. The government's continual investment in national security and other priorities shifts focus from potential R\&D and collaboration on global issues. If Turkey had been persistent in its effort to increase its $\mathrm{R} \& \mathrm{D}$ capacity in line with the original targets claimed in its Vision 2023, these could have been integrated more easily with the European S\&T structures and EU-funded research programs. Investing in areas more open to international collaboration and integration with EU policies and programs would have eventually proven more positive for Turkey's diplomacy for science efforts. These investments could have resulted in a better return in increasing productivity and GDP as well.

Barriers specific to the EU are more related to the nature of $\mathrm{EU}$ projects and funding mechanisms. The EU projects, especially the multilateral and large-scale ones, include generally bureaucratic and complex procedures (Selleslaghs, 2017, p. 29). They are usually complicated because they involve strict and timeconsuming processes not only for scientists, but especially for other stakeholders from the private sector and NGOs. These discourage some qualified candidates in Turkey from applying, especially those without prior experience with EU projects, or whose applications are deemed unsuccessful for further consideration.

The other barrier is related to Turkey's current $R \& D$ capacity and the quality of its research environment. Recent rankings of Turkey in major STI indicators based on the Global Competitiveness Index (GCI), and the UNESCO and the OECD reports, provide a general idea regarding the level of its STI competitiveness. According to the 2019 GCI, published periodically by the World Economic Forum (WEF) when evaluating economic, institutional and social indicators, Turkey is 55th among 137 countries when all 12 pillars of development are considered (WEF, 2019, p. ix) ${ }^{19}$ Although the recent data provided from the OECD indicates an increase in the per capita GDP from $\$ 19,445$ (2011) to $\$ 28,384$ (2018), and an increase in gross expenditure in R\&D (GERD) from $\$ 11.2$ billion (2011) to $\$ 18.9$ billion (2017) (OECD, 2019), Turkey is not close to its Vision 2023 aims (3\%) in GERD, which remains lower than the EU average: GERD was $0.47 \%$ in 2003 and it increased to $0.96 \%$ in 2017 , while the EU average was $1.67 \%$ in 2003 and increased to $2.06 \%$ in 2017 (OECD, 2020; Eurostat, 2020).

The 2015 UNESCO report indicates that the share of researchers in Turkey within the global number of researchers increased from $0.8 \%$ to $1.1 \%$ between 2007 and 2013, and the number of publications increased by $27.6 \%$ between 2008 and 2014 (UNESCO, 2015). However, the average citation rate remained at 0.7 (OECD average 1.08) between 2008 and 2012. This may be an indication of the scientific quality, despite an increase in the number of researchers and publications, which may be the result of lower R\&D expenditure in higher education or lower quality of its research institutions and lack of university-industry collaboration in $\mathrm{R} \& \mathrm{D}$, as reported by the GCI. Additionally, some highly qualified academics or researchers who are not comfortable with the current political environment prefer to continue their research abroad. This results in brain drain, and decreases the number and quality of the publications and international cooperation capability.

Finally, despite a weaker research environment, there are highly successful researchers in Turkey who would like to participate in multinational EU projects, but often cannot complete the application process, as they are not well-trained or have enough knowledge of writing multilateral and/or large-scale EU project proposals (Senocak, 2018, p. 21). In some cases, they are not experienced in finding partners from EU countries, which can be attributed partly to the R\&D and innovation capacity and output, limited coordinated research and innovation policy efforts, and unexploited research links with European counterparts. Therefore, they tend to apply instead for national programs, which require less competitive and complex structures for research and innovation funding mechanisms.

\section{Concluding remarks}

Hovering at the intersection of science and international relations, SD presents a new and influential area for cooperation that reaches beyond the realms of scientific communities to involve both government and academic domains. There is, as of this writing, little academic literature on SD in Turkey. In addition, Turkey's SD efforts have been largely invisible, or, at best, poorly documented. In this respect, this article builds on how the emergent notion of SD helps explain transformations and changes in Turkish STI policies by examining them with reference to Europeanization theory and in the context of the development of Turkey's SD efforts.

As an emerging market economy and a candidate country to the EU, Turkey has strived to engage in EU-supported or initiated projects and international scientific cooperation programs, beginning in the 1950s, and particularly after its candidacy status commenced at the end of 1999. Taking advantage of the EU's STI policy and research programs, Turkey has engaged in various partnerships and multilateral projects not only to develop its R\&D capacity, but also to maintain relations with the EU. All these initiatives policies and implementations, especially since the early 2000s, were aligned with European integration goals and support Turkey's position and initiatives within the Europeanization framework.

Harmonization of Turkish STI policies with the EU, as well as strengthening its international science and technology partnerships, improved its competitiveness and helped both parties to sustain relations even during political conflicts by building trust between them. In addition, using S\&T cooperation as a soft power has strengthened public diplomacy by influencing public opinion in Turkey about the EU and Europe in a favorable way, and has also contributed to changing public perception of Turkey in Europe. Furthermore, as elaborated in the "Theoretical framework" section, the EU has strengthened its international actorness by influencing stakeholders, policies, and institutions through international science cooperation and research programs.

There is no question that Turkey has benefited from S\&T engagements with the EU. However, its overall efforts to engage in the EU's research programs have mostly influenced the science for diplomacy (S4D) and diplomacy for science (D4S) aspects of its SD. Alongside these, and supporting its economic development, Turkey needs to make additional changes regarding actors, 
tools, and policies to develop a systematic and institutionalized SD policy. For instance, it needs to develop a science-based advice system at the national level and prepare a strategic plan and related policy documents for SD to strengthen Turkish foreign policy by integrating SD tools into its foreign policy-making system. At present Turkey has still not fully implemented fundamental policies and activities necessary to use science as a diplomacy tool to augment its foreign policy. In order to materialize these objectives, it needs to increase the plurality of actors in $\mathrm{SD}$, and to inform them of the importance of international S\&T cooperation and science-based advice mechanisms.

Received: 29 January 2020; Accepted: 12 January 2021;

Published online: 17 February 2021

\section{Notes}

1 In this study, the details of these bilateral agreements are not coved. But it can be a subject for further research.

2 Eight chapters were blocked by the EU Council in 2006, for Turkey's rejection to open its ports and airports to traffic from Cyprus, five by France in 2007, six chapters was frozen by Cyprus in 2009.

3 The first meeting of STIPC was made in 1989 and it was important because it defined the current state of Turkey's STI policy, and the first proposals for strengthening Turkey's R\&D capacities were presented.

4 For the implementation of Vision 2023, TUBITAK was charged with the responsibility to prepare a mid-term plan, called the "National Science and Technology Policies Implementation Plan 2005-2010".

5 In Turkish the abbreviation of TRA is TARAL (Türkiye Araștırma Alanı)

6 In this study STI, instead of science and technology (S\&T), is used to refer to policy papers, decisions at governmental, and the EU levels.

7 In Turkey there are other actors such as universities, research institutions, and affiliated institutions to the ministries such as TİKA, KOSGEB, and Turkish Patent Institute (TPE)) and some research and development organizations, such as Military Electronic Industries, (ASELSAN), Rocket Industry and Trade Inc. (ROKETSAN), Air Electronics and Industry Inc. (HAVELSAN), Otokar Automotive and Defence Industry Inc. (OTOKAR), and Turkish Aerospace Industries Corporation (TAI) work in coordination with the ministries to make researches and implement new and innovative technologies that plays roles in Turkish SD by creating connections with their counterparts in other countries in STI and research programs. There are very few NGOs working on topics related to SD, Turkish Science and Research Foundation (TUBAV) is one of those few.

8 Ministries responsible for other areas such as education, health, trade, and economy are also important in implementing STI-related policies and activities of Turkey. But only these two ministries are explored in detail as they take more direct and potential roles in Turkey's SD.

9 Formerly the Ministry of Science, Industry, and Technology.

10 Formerly the Supreme Council of Science and Technology (SCST-in Turkish BTYK). In 2018, in order to align with the new constitution, the founding by-law that was related to the establishment of was abandoned with a decree, number 703, and the Science, Technology and Innovation Policies Council (In Turkish BTYPK) was established. http://www.tubitak.gov.tr/tr/kurumsal/icerik-bilim-ve-teknoloji-yuksekkurulu. Accessed 8 December 2019.

11 Some examples for these organizations that TÜBA created relations are the European Federation of Academies of Sciences and Humanities (ALLEA), Global Network of Science Academies (IAP), The Inter Academy Council (IAC), The Inter Academy Medical Panel (IAMP), International Human Rights Network of Academies and Scholarly Societies, Association of Academies of Sciences in Asia (AASA) and International Union of Academies (IUA).

12 For the implementation of Vision 2023, TUBITAK was charged with the responsibility to prepare a mid-term plan, called the "National Science and Technology Policies Implementation Plan 2005-2010".

13 In Turkish the abbreviation of TRA is TARAL (Türkiye Araştırma Alanı).

14 For more information on development plans visit TC Cumhurbaşkanlığı Strateji ve Bütçe Başkanlığ (2020). http://www.sbb.gov.tr/kalkinma-planlari/ (30 May 2010).

15 For more information about the EU members and associated countries in Horizon 2020 and their key research-related data and recent project success stories see. https:// ec.europa.eu/research/horizon2020/index.cfm?pg=country-profiles (7 May 2020).

16 The European Research Council (ERC), as the main address for most EU countries to seek funding with its 13.1 Billion Euro budget, supports the highest quality research in Europe through competitive funding for frontier research across all fields.

17 Turkey in Horizon 2020 (2020). https://turkeyinh2020.eu/. Accessed 20 May 2020.
18 Republic of Turkey Ministry of Industry and Technology (MoIT) (2020). Bilim Diplomasisi ve Bakanlık Yurt Dışı Teşkilatının Tasarlanması. https://anahtar.sanayi gov.tr/tr/news/bilim-diplomasisi-ve-bakanlik-yurt-disi-teskilatinin-tasarlanmasi/665. Accessed 20 May 2020.

19 Turkey's ranking was lower (69th) in only innovation environment pillar, which comprises indicators regarding the capacity for innovation, the quality of scientific research institutions, company spending on $\mathrm{R} \& \mathrm{D}$, university-industry collaboration, government procurement of advanced technology, the availability of scientists and engineers, and patent applications.

\section{References}

Akçay B, Büyüktanır D (2013) Changing patterns in Turkey-EU relations: from association to full membership. In: Akçay B, Akipek Ş (eds.) Turkey's Integration into the European Union. Lexington Books, New York, Toronto, Boylder, Lanham, Plymouth, pp. 1-30

Agota D, Tamas S (2017) The potential advantages and synergies of an EU-Turkey cooperation in science technology and innovation. J Econ Coop Dev 38 (1):127-160

Apaydın Ç (2015) Bilim ve Teknoloji Yüksek Kurulu'nun (BTYK) 1989- 2014 Yılları Arasındaki Almış Olduğu Kararların Uygunluk Analizi ile İncelenmesi. Cumhuriyet Int J Educ 4(4):1-17

Avcı G, Çarkoğlu A (2011) Taking stock of the dynamics that shape EU reforms in Turkey. South Eur Soc Politics 16(2):209-219

Aydın Düzgit S, Duncker A, Huber D, Keyman F, Tocci N (eds) (2013) Global Turkey in Europe, political, economic, and foreign policy dimensions of Turkey's evolving relationship with the EU. Istituto Affari Internazionali (IAI), Rome

Aydın M, Açıkmeșe S (2009) Europeanisation through EU conditionality: understanding the new era in Turkish Foreign Policy. In: Ifantis K, Verney S (eds.) Turkey's road to European Union membership: national identity and political change. Routledge, New York, pp. 49-60

Börzel TA, Risse T (2000) When Europe Hits Home: Europeanization and domestic change. Eur Integr Online Pap 4 (15). http://eiop.or.at/eiop/texte/ 2000-015a.htm. Accessed 10 May 2020

Bölükbaşı TH, Ertugal E, Özçürümez S (2011) Avrupa Entegrasyonu Kuramlarıyla Türkiye'yi Konu Alan Yazının Etkileşimi: Avrupalılaşma Araştırma Programını Türkiye Özelinde Yeniden Düşünmek. Uluslar İlişkiler Derg 8(30):77-102

Bulmer S (2007) Theorizing Europeanization. In: Graziano P, Maarten V (eds.) Europeanization: new research agendas. Palgrave Macmillan, Basingstoke, pp. $46-58$

Büyüktanir Karacan D (2019) The effects of the Syrian Refugee crisis on the EU through the lens of social constructivism: the cases of Germany and Hungary. Altern Polit 11(1):142-167

Büyüktanir D (2018) Public diplomacy activities of TÜSİAD and MÜSİAD during the AK Party Era. Gazi Akademik Bakış 11(23):73-98

COST (2019) Brain circulation and empowering young researchers Annual Report 2019. https://www.cost.eu/wp-content/uploads/2020/04/COST-Annualreport-2020.pdf. Accessed 17 May 2020

Cowles MG, Caporaso J, Risse T (eds.) (2001) Transforming Europe: Europeanisation and domestic change. Cornell University Press, New York

De San Román AL, Schunz S (2018) Understanding European Union Science Diplomacy. J Common Market Stud 56(2):247-266

Dolan B (2012) Science and technology agreements as tools for science diplomacy: a U.S. case study Sci Dipl 1(4):1-9. http://www.sciencediplomacy.org/article/ 2012/science-and-technology-agreements-tools-forscience-diplomacy

Ekşi M (2016) The rise and fall of soft power in Turkish Foreign Policy during JDP. Lambert Academic Publishing, Saarbrücken

Erdil E, Gossart C (2009) Appraising the integration of sustainable development into sectoral policies: the case of Turkish Science \& Technology policies. Science and Technology Policies Research Center Tekpol Working Paper Series $09 / 01$

EUREKA (2020) Turkey. https://www.eurekanetwork.org/countries/turkey/. Accessed 20 May 2020

EUR-Lex (2012) Consolidated versions of the Treaty on European Union and the Treaty on the Functioning of the European Union, Official Journal C 326, 26/10/2012. https://eur-lex.europa.eu/legal-content/EN/TXT/HTML/? uri=CELEX:12012E/TXT. Accesses 1 June 2020

European Parliament (2015) Briefing 'EU scientific cooperation with third countries'. http://www.europarl.europa.eu/thinktank/en/document.html? reference=EPRS_BRI(2015)564393. Accessed 1 Nov 2019

European Commission (2020a) Trade Policy-countries and regions. https://ec.europa. eu/trade/policy/countries-and-regions/countries/turkey/. Accessed 27 Apr 2020.

European Commission (2020b) Horizon 2020 country profiles. https://ec.europa.eu/ research/horizon2020/index.cfm?pg=country-profiles. Accessed 7 May 2020

European Commission (2019a) Horizon 2020 projects. https://ec.europa.eu/ programmes/horizon2020/en/h2020-sections-projects. Accessed 1 Nov 2019

European Commission (2019b) H2020-Marie Skłodowska-Curie Actions (MSCA) country fact sheet. 25/11/19 Turkey (TR). Available at https://ec.europa.eu/ 
research/mariecurieactions/sites/mariecurie2/files/msca-country-profileturkey-2019_en.pdf. Accessed 12 Dec 2019

European Commission (2016) Priorities for international cooperation in research and innovation. 13.10.2016 COM (2016) 657 final, Brussels

European Commission (2006) Turkey 2006 progress report COM (2006) 649 final, Brussels https://ec.europa.eu/neighbourhoodenlargement/sites/ near/files/pdf/key_documents/2006/nov/tr_sec_1390_en.pdf. Accessed 2 May 2020

Eurostat (2020) R\&D expenditure. https://ec.europa.eu/eurostat/statisticsexplained/index.php/R_\%26_D_expenditure. Accessed 22 May 2020

Flink T (2020) International joint research programming. In: Young M, Flink T, Dall E (eds) Science Diplomacy in the Making: case-based insights from the S4D4C project. Online Book. https://www.s4d4c.eu/wp-content/uploads/ 2020/03/special.pdf. Accessed 12 Apr 2020

Flink T, Schreiterer U (2010) Science diplomacy at the intersection of S\&T policies and foreign affairs: toward a typology of national approaches. Sci Public Policy 37(9):665-677

Geothermica (2020) http://www.geothermica.eu/about-geothermica/participants/ turkey---scientific-and-technological-research-council-of-turkey-tubitak/. Accessed 1 Dec 2019

Grigoriadis IN (2008) On the Europeanisation of minority rights protection: comparing the cases of Greece and Turkey. Mediterranean Politics 13 (1):23-41

Holsti OR (1968) Content analysis. Chapter 16. In: Lindzey G, Aronson E (eds.) The handbook of social psychology, 2nd edn. Addison-Wesley, Reading, pp. $596-992$

Holsti OR (1968) Content analysis. In: Lindzey G, Aronson E (eds.) The handbook of social psychology, 2nd edn, vol. 2. Addison-Wesley, Reading, pp. 596-692

IMF (2020) IMF Turkey at a glance https://www.imf.org/en/Countries/TUR. Accessed 2 Jun 2020.

Kalibar A (2013) Contextual and contested, reassessing Europeanization: the case of Turkey. Paper presented at the 7th ECPR General Conference. Sciences Po, Bordeaux

Kaya A, Tecmen A (2011) The role of common cultural heritage in external promotion of modern Turkey: Yunus Emre Cultural Centres. Working paper no. $4 \mathrm{EU} / 4 / 2011$

Olsen JP (2002) The many faces of Europeanisation. J Common Market Stud 40 (5):921-52

Müftüler-Baç M (2017) Turkey's future with the European Union: an alternative model of differentiated integration. Turk Stud 18(3):416-438

Müftüler-Baç M (2005) Turkey's political reforms and the impact of the European Union. South Eur Soc Politics 10(1):16-30

OECD (2020) Data, innovation and technology. https://data.oecd.org/rd/grossdomestic-spending-on-r-d.htm. Accessed 22 May 2020

OECD (2019) Country statistical profiles: key tables from OECD. https://www. oecd-ilibrary.org/economics/country-statistical-profiles-key-tables-fromoecd_20752288?page $=3$. Accessed 12 Dec 2019

Oğuzlu T (2008) Middle easternization of Turkey's foreign policy: does Turkey dissociate from the west? Turk Stud 9(1):3-20

Olcay B (2011) Bilim Diplomasisi. Ankara, Seçkin

Ozer-Imer I, Imer S (2020) The political economy of restructuring in science and technology in Turkey. Eur Rev 1-14. https://doi.org/10.1017/ S1062798720000083.

Öniş Z, Yllmaz Ş (2009) Between Europeanisation and Euro-Asianism: foreign policy activism in Turkey during the AKP era. Turk Stud 10(1):7-24

Özkaraöz Doğan E (2015) Science diplomacy in the global age: examples from Turkey and the world. Doctorate Thesis, Middle East Technical University, Ankara

Pearlman CP, Vinson C, Singh Tet al (2016) Multi-stakeholder partnerships: breaking down barriers to effective cancer-control planning and implementation in low- and middle-income countries Sci Dipl 5(1):1-15. http:// www.sciencediplomacy.org/article/2016/multi-stakeholderpartnerships

Republic of Turkey Ministry of Industry and Technology (MoIT) (2020) Bilim Diplomasisi ve Bakanlık Yurt Dışı Teşkilatııın Tasarlanması. https://anahtar. sanayi.gov.tr/tr/news/bilim-diplomasisi-ve-bakanlik-yurt-disi-teskilatinintasarlanmasi/665. Accessed 20 May 2020

Republic of Turkey Ministry of Industry and Technology (2019a). https://ab.sanayi. gov.tr/handlers/DokumanGetHandler.ashx?dokumanId=1066c663-1c4846f9-94c6-27c0bc8c7604 Accessed8 Nov 2019

Republic of Turkey Ministry of Industry and Technology (2019b). Avrupa Birliği Üyesi Ülkeler, Avrupa Ekonomik Alanı Ülkeleri (İzlanda, Lihtenştayn, Norveç) ve İsviçre ile Kuzey Kıbrıs Türk Cumhuriyeti (KKTC) İle İkili İlişkiler. https://ab.sanayi.gov.tr/handlers/DokumanGetHandler. ashx?dokumanId=2ccfd8de-089d-4dde-8b9e-824160530d95. Accessed 22 Nov 2019

Ruffini PB (2017) Science and diplomacy: a new dimension of international relations. Springer, Cham
Rüffin N (2017) Science and technology agreements in the toolbox of science diplomacy: effective instruments or insignificant add-ons? EL-CSID Working Paper 6

Samur H (2009) Turkey's Europeanisation process and the return of the Syriacs. Turk Stud 10(3):327-340

San Román L, Schunz AS (2018) Understanding European Union science diplomacy. J Common Market Stud 56(2):247-266

Schimmelfennig F, Sedelmeier U (eds.) (2015) The Europeanization of Central and Eastern Europe. Cornell University Press, Ithaca, London

Schimmelfennig F, Sedelmeier U (2007) Candidate countries and conditionality. In: Graziano P, Vink MP (eds.) Europeanisation: new research agendas. Palgrave, Basingstoke

Schimmelfennig F, Engert S, Knobel H (2003) Costs, commitment and compliance: the impact of EU democratic conditionality on Latvia, Slovakia and Turkey. J Common Market Stud 41(3):495-518

Selleslaghs J (2017) EU-Latin American science diplomacy. Working Paper. Issue 2017/8

Senocak NS (2018) Case study report. The perception of the EU cultural and science diplomacy in Turkey issue 2018/14. Working paper Institute for European Studies

Smith CL (2012) Synchrotron light and the Middle East: bringing the region's scientific communities together through SESAME Sci Dipl 1(4):1-8. http://www.sciencediplomacy.org/perspective/2012/synchrotron-lightand-middle-east

TC Cumhurbaşkanlığı Strateji ve Bütçe Başkanlığı (2020) Developing plans. http:// www.sbb.gov.tr/kalkinma-planlari/ Accessed 30 May 2020

Tocci N (2006) The Europeanization of Turkey's Kurdish question. In: Joseph (ed.) Turkey and the European Union: internal dynamics and external challenges. Palgrave Macmillan, New York

Trobbiani R, Hatenboer C (2018) The future of EU science diplomacy: conceptual and strategic reflections. United Nations University Institute on Comparative Regional Integration Studies (UNU-CRIS). Policy Paper. Issue 2018/14 http://cris.unu.edu/sites/cris.unu.edu/files/EL-CSID\%20Policy\%20Paper\% 202018-14.pdf. Accessed 13 Oct 2019

The Royal Society (2010) New frontiers in science diplomacy Navigating the changing balance of power. RS Policy document 01/10. January 2010 Royal Society, London

Turkey in Horizon 2020 (2020) https://turkeyinh2020.eu/ Accessed 1 Jun 2020

Turkish Ministry of Foreign Affairs-Directorate for EU Affairs (2020a) Chapter 25-Science and Research. https://www.ab.gov.tr/90_en.html. Accessed 20 May 2020

Turkish Ministry of Foreign Affairs -Directorate of EU Affairs (2020b) Current situation https://www.ab.gov.tr/current-situation_65_en.html. Accessed 1 May 2020

Turkish Ministry of Foreign Affairs (MFA) (2020a) Turkey's enterprising and humanitarian Foreign Policy. http://www.mfa.gov.tr/synopsis-of-the-turkishforeign-policy.en.mfa. Accessed 15 May 2020

Turkish Ministry of Foreign Affairs (2020b) Turkey's enterprising and humanitarian Foreign Policy http://www.mfa.gov.tr/synopsis-of-the-turkish-foreignpolicy.en.mfa. Accessed 2 Jun 2020

TÜBA (2020a) Bilateral relations. http://www.tuba.gov.tr/en/internationalrelations/bilateral-relations Accessed 28 Nov 2019

TÜBA (2020b) Multilateral relations. http://www.tuba.gov.tr/en/internationalrelations/multilateral-relations. Accessed 28 Apr 2020

TÜBITAK (2019) Hakkımızda. https://www.tubitak.gov.tr/tr/icerik-hakkimizda. Accessed 2 Nov 2019

TÜBİTAK (2004) Ulusal Bilim ve Teknoloji Politikaları 2003-2023 Strateji Belgesi https://www.tubitak.gov.tr/tubitak_content_files/vizyon2023/ Vizyon2023_Strateji_Belgesi.pdf Accessed 28 Apr 2019

TÜBİTAK (2003) Bilim ve Teknoloji Yüksek Kurulu Dokuzuncu Toplantısı. https://www.tubitak.gov.tr/tubitak_content_files/BTYPD/btyk/9/ 9btyk_hazirliknotlari.pdf. Accessed 1 Jun 2020

Ufuk 2020 (2020) Recent developments in integration of TARAL to ERA. Presentation by Hasan Mandal (TÜBİTAK President) https://ufuk2020.org.tr/ sites/default/files/u58/hasan mandal_tubitak.pdf Accessed 20 May 2020

Ulutaş-Aydoğan S (2015) Turkish science, technology and innovation policy for economic development within the context of European integration. Lit, Zurich

Ufuk 2020 (2019) ERC and Turkey. https://ufuk2020.org.tr/en/h2020/erc/erc-andturkey. Accessed 22 Nov 2019

UNESCO (2015) The UNESCO 2015 science report. http://uis.unesco.org/sites/ default/files/documents/unesco-science-report-towards-2030-part1.pdf. Accessed 8 Dec 2019

Van Langenhove L (2017) Tools for an EU Science Diplomacy. European Commission Directorate-General for Research and Innovation (10.27777/911223) Publications Office of the European Union, Luxemburg

Van Langenhove L (2016) Global Science Diplomacy as a new tool for Global Governance. United Nations University, Vrije Universiteit, Brussel

WEF World Economic Forum (2019) The global competitiveness report 2019. Available at http://www3.weforum.org/docs/GCR20172018/05FullReport/ 
TheGlobalCompetitivenessReport2017\%E2\%80\%932018.pdf. Accessed 13 Dec 2019

Yunus Emre Instutute (2019a) What is the Yunus Emre Institute?. https://www. tabip.global/ecosystem/views/portalHeader/Yunus-Emre-Enstitusu-Nedir-2. Accessed 22 Nov 2019

Yunus Emre Instutute (2019b) Yunus Emre Institute. https://www.yee.org.tr/en/ corporate/yunus-emre-institute. Accessed 22 Nov 2019

Yunus Emre Instutute (2019c) Yunus Emre Enstitüsü, "THY Bilim Elçileri Zirvesi"nde. https://www.yee.org.tr/tr/haber/yunus-emre-enstitusu-thybilim-elcileri-zirvesinde. Accessed 22 Nov 2019

\section{Competing interests}

The author declares no competing interests.

\section{Additional information}

Correspondence and requests for materials should be addressed to D.B.K.

Reprints and permission information is available at http://www.nature.com/reprints
Publisher's note Springer Nature remains neutral with regard to jurisdictional claims in published maps and institutional affiliations.

\section{(c) (1)}

Open Access This article is licensed under a Creative Commons Attribution 4.0 International License, which permits use, sharing, adaptation, distribution and reproduction in any medium or format, as long as you give appropriate credit to the original author(s) and the source, provide a link to the Creative Commons license, and indicate if changes were made. The images or other third party material in this article are included in the article's Creative Commons license, unless indicated otherwise in a credit line to the material. If material is not included in the article's Creative Commons license and your intended use is not permitted by statutory regulation or exceeds the permitted use, you will need to obtain permission directly from the copyright holder. To view a copy of this license, visit http://creativecommons.org/ licenses/by/4.0/.

(C) The Author(s) 2021 